\title{
Contribution of nitrogen from urea applied at different rates and times on grapevine nutrition
}

\author{
Gustavo Brunetto ${ }^{\mathrm{a}, *}$, Carlos Alberto Ceretta ${ }^{\mathrm{a}}$, George Wellington Bastos de Melo ${ }^{\mathrm{b}}$, \\ Eduardo Girotto ${ }^{c}$, Paulo Ademar Avelar Ferreira ${ }^{a}$, Cledimar Rogério Lourenzi ${ }^{\mathrm{d}}$, \\ Rafael da Rosa Couto ${ }^{a}$, Adriele Tassinaria ${ }^{a}$, Rodrigo Knevitz Hammerschmitt ${ }^{a}$, \\ Lincon Oliveria Stefanello da Silva ${ }^{a}$, Bruno Pedro Lazzaretti ${ }^{a}$, \\ Matheus Severo de Souza Kulmann ${ }^{\text {a }}$, Corina Carranca ${ }^{\mathrm{e}}$ \\ a Department of Soil Science of the Federal University of Santa Maria, C.P. 221, CEP 97105-900 Santa Maria, RS, Brazil \\ ${ }^{\mathrm{b}}$ Embrapa Uva e Vinho, C.P. 130, Rua Livramento 515, Bento Gonçalves, CEP 95700-000 RS, Brazil \\ ${ }^{c}$ Federal Institute of Education, Science and Technology of the Rio Grande do Sul, Rua Nelsi Ribas Fritsch 1111, Ibirubá, CEP $98200-000$ RS, Brazil \\ d Department of Rural Engineering of the Federal University of Santa Catarina, Rodovia Admar Gonzaga 1346, Florianópolis, CEP 88034-000 SC, Brazil \\ e Instituto Nacional de Investigação Agrária e Veterinária, Quinta do Marquês, Av. República, Nova Oeiras, Portugal
}

\section{A R T I C L E I N F O}

\section{Article history:}

Received 14 August 2015

Received in revised form 23 March 2016

Accepted 8 May 2016

\section{Keywords:}

${ }^{15} \mathrm{~N}$ uptake

$\mathrm{N}$ derived from fertilizer

Plant N distribution

Residual soil N

Vitis vinifera

\begin{abstract}
A B S T R A C T
In Brazilian vineyards planted in sandy soils, nitrogen (N) should be applied at optimal rates and timing that correspond to greatest demand, thus minimizing $\mathrm{N}$ losses. The aim of this study was to evaluate the grapevine $\mathrm{N}$ distribution and recovery of urea- ${ }^{15} \mathrm{~N}$ applied at budding and bloom. In 2009, in a vineyard (Vitis vinifera cv. Cabernet Sauvignon) planted in Santana do Livramento, south Brazil, grapevines were treated with $10 \mathrm{~kg} \mathrm{Nha}^{-1}$ at budding $+10 \mathrm{~kg} \mathrm{Nha}^{-1}$ at full bloom (10B $\left.+10 \mathrm{~F}\right) ; 20 \mathrm{~kg} \mathrm{Nha}^{-1}$ at budding $+20 \mathrm{~kg} \mathrm{~N} \mathrm{ha}^{-1}$ at full bloom (20B $\left.+20 \mathrm{~F}\right) ; 20 \mathrm{~kg} \mathrm{~N} \mathrm{ha}^{-1}$ at budding (20B); and $40 \mathrm{~kg} \mathrm{~N} \mathrm{ha}^{-1}$ at full bloom (40F). Budding of grapevines in 2009 and 2010 was at the end of August and full bloom in November. In February 2010 and 2011, grapevine organs (leaves, berries, stem and roots) were collected, and in February 2011 soil samples were also collected in the profile. The wine-producing grapevines grown in the sandy soil took up more $\mathrm{N}$ derived from $20 \mathrm{~B}$ treatment, compared with other $\mathrm{N}$ treatments, especially in the first crop season. The $\mathrm{N}$ derived from fertilizer applied at different rates and time was preferentially distributed in annual plant organs, but most $\mathrm{N}$ contained in the plant organs was derived from other sources than the fertilizer N. In the following season, ${ }^{15} \mathrm{~N}$ applied in the previous year was recovered preferentially in leaves and fruits, again in low amounts. Nitrogen derived from fertilizer applied at different rates and time in a sandy soil apparently contributes little to grapevine nutrition.
\end{abstract}

(C) 2016 Elsevier B.V. All rights reserved.

\section{Introduction}

Sandy soils planted with vineyards normally have low to medium organic matter content which gives them a low capacity for supplying grapevines with mineral nitrogen (N) (Brunetto et al., 2007). Therefore, some wine producers maintain legumes in the inter-row spacing to promote the sumbiotic fixation of atmospheric $\mathrm{N}_{2}$. During decomposition of shoots of cover crops in the soil surface and roots below the surface, $\mathrm{N}$ contained in the plant tissue is released within the root zone of grapevines and is taken

\footnotetext{
* Corresponding author.

E-mail address: brunetto.gustavo@gmail.com (G. Brunetto).
}

up in small amounts by these crops (Brunetto et al., 2011, 2014). However, usually grapevines show low levels of $\mathrm{N}$ in the leaves $\left(<16 \mathrm{~g} \mathrm{~N} \mathrm{~kg}^{-1}\right.$ ) (CQFS-RS/SC, 2004). This may cause a decline in crop yield and negatively affect the composition of grape. Thus, the addition of a mineral $\mathrm{N}$ source such as urea has been recommended.

Application of urea on the soil surface, it is rapidly hydrolyzed by urease extracellular enzymes produced by microorganisms such as bacteria, actinobacteria and soil fungi and produces ammonium carbonate $\left(\mathrm{NH}_{4}{ }^{+}\right)_{2} \mathrm{CO}_{3}$ which is not stable in the soil. In the presence of water it decomposes into $\mathrm{HCO}_{3}{ }^{-}, \mathrm{OH}^{-}$and ammonium $\left(\mathrm{NH}_{4}{ }^{+}\right)$. The $\mathrm{HCO}_{3}{ }^{-}$may then decompose into $\mathrm{CO}_{2}$ and $\mathrm{OH}^{-}$. If the $\mathrm{NH}_{4}{ }^{+}$ reacts with $\mathrm{OH}^{-}$, a loss of $\mathrm{NH}_{3}$ can occur to the atmosphere. However, part of $\mathrm{NH}_{4}{ }^{+}$is transformed through biological oxidation into nitrite $\left(\mathrm{NO}_{2}{ }^{-}\right)$followed by nitrate $\left(\mathrm{NO}_{3}{ }^{-}\right)$which may be taken up 
by plant roots or lost by leaching, especially in soils with a sandy texture (Barlow et al., 2009; Lorensini et al., 2012). However, the amount of $\mathrm{N}$ leached is especially dependent on the amount of $\mathrm{N}$ in the soil and the volume of rainfall (Nielsen et al., 1982; Hajrasuliha et al., 1998). A strategy for minimizing the $\mathrm{NO}_{3}{ }^{-}$leaching losses in the soil profile is to apply the fertilizer $\mathrm{N}$ at phenological stages with greater crop N demand (Conradie, 1990, 1991).

Literature shows contradicting results as to the most appropriate time for $\mathrm{N}$ application for grapevines production (Spayd et al., 1991). Some studies report that grapevines recover a satisfactory amount of $\mathrm{N}$ from fertilizer applied at the beginning of budding-this was shown by Conradie (1991) in South Africa, Löhnertz (1991) in Germany, Glad et al. (1994) in France, Araujo et al. (1995) in California, the United States and Brunetto et al. (2006b) in the south of Brazil. Most of these authors attribute this fact to mild temperatures and proper soil moisture at the end of winter which increases the activity of the microbial population in the soil and consequently the availability of mineral $\mathrm{N}$ in the soil. Also the emergence of active roots is greater at this time Brunetto et al. (2006b, 2014). However, Vos et al. (2004) in the United States and Schreiner and Scagel (2006) observed that grapevines recovered more $\mathrm{N}$ when fertilizer was applied from blooming to six weeks after blooming, in comparison with the application at the beginning of budding with a crop recovery of $\mathrm{N}$ greater than $20 \%$.

Part of $\mathrm{N}$ taken up by the crop is incorporated into the carbonate structures, such as allantoin (4N:4C), arginine (4N:4C), and citrulline (3N:3C), or, moreover, in mineral forms, such as $\mathrm{NH}_{4}{ }^{+}$ and $\mathrm{NO}_{3}{ }^{-}$transported through the stem and branches older than one year to the vegetative organs with active cell division and consequently with a higher dry matter increase, such as leaves, shoots, and bunches (berries + rachis) (Glad et al., 1994). Part of accumulated $\mathrm{N}$ in the annual organs throughout the period of leaf senescence may be redistributed to the perennial organs, especially to roots and stem/trunk (Bates et al., 2002; Zapata et al., 2004; Brunetto et al., 2005, 2006a, 2014). For studies on N recovery and accumulation in organs of fruit-bearing plants like grapevines, ${ }^{15} \mathrm{~N}$ isotope has been used as a tracer since it allows a precise monitoring of fertilizer $\mathrm{N}$ taken up by the crop and its distribution in the plant (Brunetto et al., 2006a,b; Menino et al., 2007; Neto et al., 2008).

The aim of this study was to evaluate the grapevine $\mathrm{N}$ distribution and recovery of urea- ${ }^{15} \mathrm{~N}$ applied at budding and bloom. We hypothesized that fertilizer $\mathrm{N}$ applied at blooming in the previous year is remobilized for vegetative and flowering organs in the following season, whereas $\mathrm{N}$ applied at budding is especially used in the current season.

\section{Materials and methods}

\subsection{Description of the experiment}

The experiment was conducted from September 2009 to February 2012 in a vineyard at Santana do Livramento, Rio Grande do Sul-Brazil (longitude $655321.09 \mathrm{~m} \mathrm{E}$; latitude $6593897.74 \mathrm{~m}$ $\mathrm{S})$. The vineyard (Vitis vinifera) was the Cabernet Sauvigon cultivar grafted on SO4 (Vitis berlandieri $\times$ Vitis riparia) rootstock. Plant density per hectare was $3703(1.0 \mathrm{~m} \times 2.7 \mathrm{~m})$ on a spur pruned cordon system. Climate in the region is subtropical humid, $\mathrm{Cfa} 2$ type, according to the Köppen classification and is characterized by mild temperature and rainfall with little variation throughout the year. Mean annual rainfall for a long period is $1600 \mathrm{~mm}$; the mean temperature of the hottest month (January) is $23.8^{\circ} \mathrm{C}$ and the mean temperature of the coldest month (July) is $12.4^{\circ} \mathrm{C}$. Data on mean monthly temperature and accumulated rainfall throughout the experimental period are shown in Table 1 . The soil is a
Table 1

Mean monthly values of rainfall $(\mathrm{mm})$, air temperature $\left({ }^{\circ} \mathrm{C}\right)$, and air relative humidity (\%RH) during the experimental period.

\begin{tabular}{llclc}
\hline Year/Month & $\begin{array}{l}\text { Phenological } \\
\text { Stage }\end{array}$ & $\begin{array}{c}\text { Rainfall } \\
(\mathrm{mm})\end{array}$ & $\begin{array}{l}\text { Air temperature } \\
\left({ }^{\circ} \mathrm{C}\right)\end{array}$ & $\begin{array}{c}\text { Air RH } \\
(\%)\end{array}$ \\
\hline $\begin{array}{l}\text { 2009 } \\
\text { August }\end{array}$ & Begin of budbreak & 45.3 & 14.2 & 77.9 \\
September & Budbreak & 269.4 & 13.3 & 86.6 \\
October & End of budbreak & 135.9 & 16.9 & 77.8 \\
November & Begin of bloom & 540.8 & 20.8 & 86.7 \\
December & End of bloom & 219.0 & 21.7 & 79.2 \\
2010 & & & & \\
January & Veraison & 204.1 & 23.4 & 77.3 \\
February & Veraison & 240.7 & 23.1 & 82.8 \\
March & Harvest & 58.9 & 21.8 & 79.9 \\
April & Start falling leaves & 132.0 & 17.1 & 86.8 \\
May & falling leaves & 133.4 & 14.3 & 84.0 \\
June & falling leaves & 33.7 & 12.1 & 80.9 \\
July & End of falling leaves & 295.3 & 10.9 & 78.5 \\
August & Budbreak & 53.3 & 11.6 & 81.2 \\
September & Budbreak & 182.6 & 14.4 & 68.1 \\
October & End of budbreak & 19.4 & 16.2 & 59.8 \\
November & Begin of bloom & 29.0 & 19.7 & 57.3 \\
December & End of bloom & 56.0 & 23.7 & \\
2011 & & & & 70.3 \\
January & Veraison & 61.6 & 25.0 & \\
\hline
\end{tabular}

Table 2

Main physical and chemical characteristics of the soil in the experimental site at 0 $-0.20 \mathrm{~m}$ soil layer.

\begin{tabular}{lll}
\hline Soil characteristics & Unit & $0-0.20 \mathrm{~m}$ \\
\hline Clay & $\mathrm{g} \mathrm{kg}^{-1}$ & 63 \\
Silt & $\mathrm{g} \mathrm{kg}^{-1}$ & 115 \\
Sand & $\mathrm{g} \mathrm{kg}^{-1}$ & 822 \\
Organic matter & $\mathrm{g} \mathrm{kg}^{-1}$ & 15.0 \\
Total N & $\mathrm{mg} \mathrm{kg}^{-1}$ & 2.300 \\
$\left.\mathrm{pH}_{(\mathrm{H}} \mathrm{O}\right)$ & - & 6.00 \\
Exchangeable aluminum & & 0.00 \\
Exchangeable magnesium & $\mathrm{cmol}_{\mathrm{c}} \mathrm{kg}^{-1}$ & 0.80 \\
Exchangeable calcium & $\mathrm{cmol}_{\mathrm{c}} \mathrm{gg}^{-1}$ & 1.75 \\
Exchangeable potassium & $\mathrm{mg} \mathrm{kg}^{-1}$ & 50.0 \\
Available phosphorus & $\mathrm{mg} \mathrm{kg}^{-1}$ & 40.0 \\
\hline
\end{tabular}

Typic Hapludalf and the chemical properties in the $0-0.20 \mathrm{~m}$ layer are shown in Table 2. Plants in the inter-rows spacing were desiccated with non-residual herbicide. In this inter-rows, a mixture of plants was cultivated, especially the Paspalum notatum, Trifolium repens and Lolium perenne.

In 2009, grapevines received the following four treatments: $10 \mathrm{~kg} \mathrm{Nha}^{-1}$ at budding $+10 \mathrm{~kg} \mathrm{Nha}^{-1}$ at full bloom $(10 \mathrm{~B}+10 \mathrm{~F})$; $20 \mathrm{~kg} \mathrm{Nha}^{-1}$ at budding $+20 \mathrm{~kg} \mathrm{Nha}^{-1}$ at full bloom $(20 \mathrm{~B}+20 \mathrm{~F})$; $20 \mathrm{~kg} \mathrm{~N} \mathrm{ha}^{-1}$ at budding (20B); and $40 \mathrm{~kg} \mathrm{~N} \mathrm{ha}^{-1}$ at full bloom (40F). Budding of grapevines in 2009 and 2010 was at the end of August, and full bloom in November. The $\mathrm{N}$ source was urea enriched with $3 \%{ }^{15} \mathrm{~N}$ atom excess. The urea was incorporated into the soil surface in the row, below the of grapevine canopy. In addition, five plants without ${ }^{15} \mathrm{~N}$ application were used as control plants. The experimental design was under randomized blocks with five replications, with three central plants in each plot being used for measurements. The leaves of grapevines collected in the veraison contained (\%): $0.90 \mathrm{~N}, 0.2 \mathrm{P}, 2.0 \mathrm{~K}, \mathrm{Ca} 1.5$ and $0.4 \mathrm{Mg}$.

In February 2010 and 2011, eight bunches of grapes were collected randomly from each grapevine. Then, berries from the upper, middle and lower part of each bunch were separated and frozen in liquid $\mathrm{N}$, dried in a freeze-dryer until constant weight, and reserved for testing. The eight rachis of bunches were also reserved for analysis. Afterwards, mature leaves were collected from the middle third of three shoots chosen at random in each plant. Leaves and rachis 


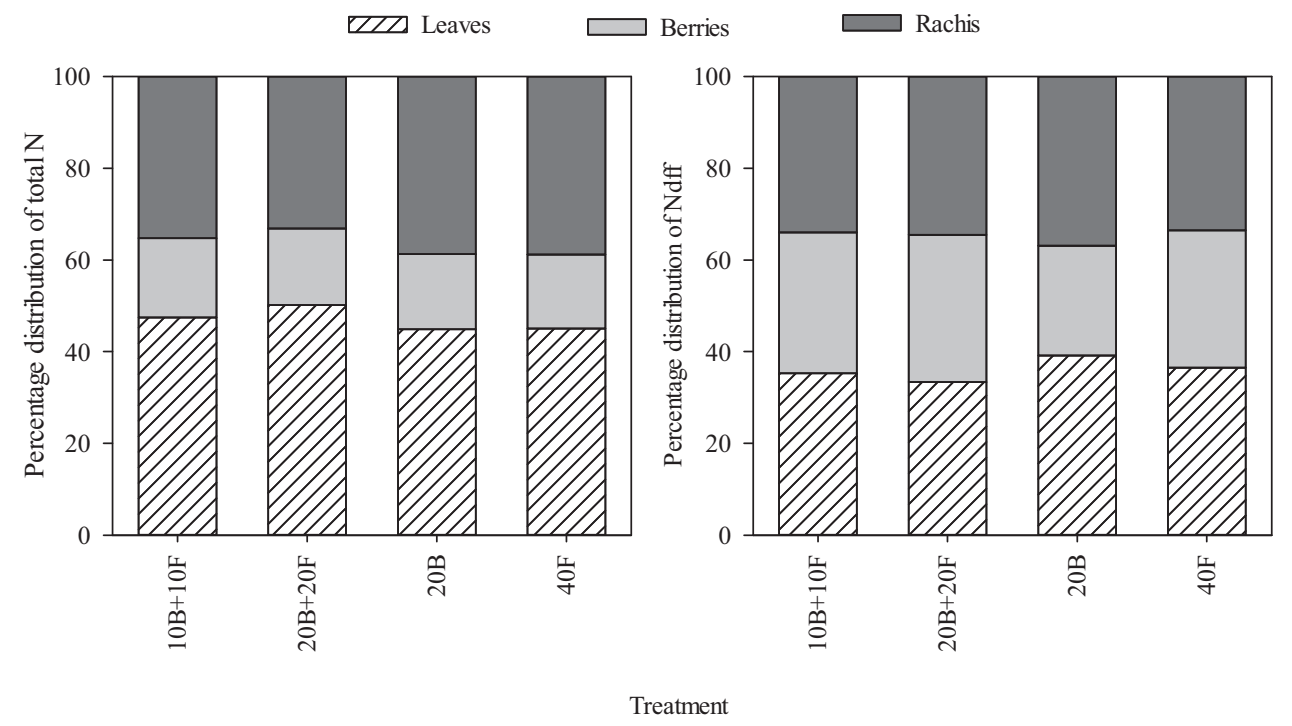

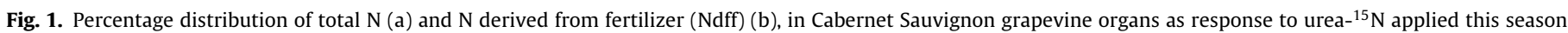

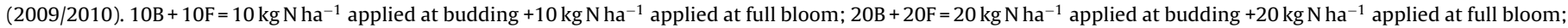
$20 \mathrm{~B}=20 \mathrm{~kg} \mathrm{~N} \mathrm{ha}^{-1}$ applied at budding; $40 \mathrm{~F}=20 \mathrm{~kg} \mathrm{~N} \mathrm{ha}^{-1}$ applied at budding.

Table 3

Total $\mathrm{N}(\%)$, atom $\%{ }^{15} \mathrm{~N}$ excess, $\mathrm{N}$ derived from fertilizer (\%Ndff), and $\mathrm{N}$ derived from other sources (\%Ndfs) in Cabernet Sauvignon grapevine organs as response to urea${ }^{15} \mathrm{~N}$ applied this season $(2009 / 2010)$.

\begin{tabular}{lllll}
\hline Treatment & Leaves & Berries & Rachis & CV (\%) \\
\hline & Total N (\%) & & & \\
$10 \mathrm{~B}+10 \mathrm{~F}$ & $2.33 \mathrm{bA}^{\mathrm{a}}$ & $0.85 \mathrm{aC}$ & $1.73 \mathrm{aB}$ & 22.74 \\
$20 \mathrm{~B}+2 \mathrm{~F}$ & $3.03 \mathrm{aA}$ & $1.01 \mathrm{aC}$ & $2.00 \mathrm{aB}$ & 10.58 \\
$20 \mathrm{~B}$ & $2.10 \mathrm{bA}$ & $0.77 \mathrm{aB}$ & $1.81 \mathrm{aA}$ & 7.89 \\
$40 \mathrm{~F}$ & $2.37 \mathrm{bA}$ & $0.85 \mathrm{aB}$ & $2.04 \mathrm{aA}$ & 6.73 \\
$\mathrm{CV}(\%)$ & 8.78 & 16.11 & 16.78 & \\
& Atom\% & & & \\
$10 \mathrm{~B}+10 \mathrm{~F}$ & $0.120 \mathrm{bA}$ & $0.104 \mathrm{aA}$ & $0.116 \mathrm{bA}$ & 13.53 \\
$20 \mathrm{~B}+20 \mathrm{~F}$ & $0.133 \mathrm{bA}$ & $0.128 \mathrm{aA}$ & $0.137 \mathrm{bA}$ & 5.90 \\
$20 \mathrm{~B}$ & $0.218 \mathrm{aA}$ & $0.133 \mathrm{aB}$ & $0.205 \mathrm{aA}$ & 6.46 \\
$40 \mathrm{~F}$ & $0.127 \mathrm{bA}$ & $0.104 \mathrm{aA}$ & $0.116 \mathrm{bA}$ & 3.72 \\
$\mathrm{CV}(\%)$ & 4.90 & 8.42 & 6.78 & \\
& $\% \mathrm{Ndff}$ & & & \\
$10 \mathrm{~B}+10 \mathrm{~F}$ & $4.00 \mathrm{bA}$ & $3.48 \mathrm{aA}$ & $3.85 \mathrm{bA}$ & 13.48 \\
$20 \mathrm{~B}+20 \mathrm{~F}$ & $4.42 \mathrm{bA}$ & $4.26 \mathrm{aA}$ & $4.57 \mathrm{bA}$ & 5.71 \\
$20 \mathrm{~B}$ & $7.27 \mathrm{aA}$ & $4.45 \mathrm{aB}$ & $6.84 \mathrm{aA}$ & 6.36 \\
$40 \mathrm{~F}$ & $4.23 \mathrm{bA}$ & $3.47 \mathrm{aA}$ & $3.88 \mathrm{bA}$ & 3.82 \\
$\mathrm{CV}(\%)$ & 4.95 & 8.39 & 6.72 & \\
& $\% \mathrm{Ndfs}$ & & & \\
$10 \mathrm{~B}+10 \mathrm{~F}$ & $96.00 \mathrm{aA}$ & $96.52 \mathrm{aA}$ & $96.15 \mathrm{aA}$ & 0.53 \\
$20 \mathrm{~B}+20 \mathrm{~F}$ & $95.58 \mathrm{aA}$ & $95.74 \mathrm{aA}$ & $95.43 \mathrm{aA}$ & 0.26 \\
$20 \mathrm{~B}$ & $92.73 \mathrm{bB}$ & $95.56 \mathrm{aA}$ & $93.16 \mathrm{bB}$ & 0.42 \\
$40 \mathrm{~F}$ & $95.77 \mathrm{aA}$ & $96.53 \mathrm{aA}$ & $96.12 \mathrm{aA}$ & 1.12 \\
$\mathrm{CV}(\%)$ & 0.92 & 0.34 & 0.34 & \\
\hline
\end{tabular}

a Mean values followed by the same lowercase in the column and uppercase in the line do not differ among them according to the Scott-Knott test at 5\% probability. $10 \mathrm{~B}+10 \mathrm{~F}=10 \mathrm{~kg} \mathrm{~N}^{-1}$ applied at budding $+10 \mathrm{~kg} \mathrm{~N} \mathrm{ha}^{-1}$ applied at full bloom; $20 \mathrm{~B}+20 \mathrm{~F}=20 \mathrm{~kg} \mathrm{Nha}^{-1}$ applied at budding $+20 \mathrm{~kg} \mathrm{Nha}^{-1}$ applied at full bloom; $20 \mathrm{~B}=20 \mathrm{~kg} \mathrm{~N} \mathrm{ha}^{-1}$ applied at budding; $40 \mathrm{~F}=20 \mathrm{~kg} \mathrm{~N} \mathrm{ha}^{-1}$ applied at budding; $\mathrm{CV}=$ coefficient of variation.

were dried in an air circulation oven at $65^{\circ} \mathrm{C}$ until constant weight, and were sieved $(<0.05 \mathrm{~mm})$ and reserved for testing.

In February 2011, shoots and leaves were collected at random from each plant. The 1-year-old shoots were also collected each plant and prepared for analysis. For each stem, a strip of about $0.05 \mathrm{~m}$ length, representing around $1 / 4$ of the diameter of the stem was collected at $0.4 \mathrm{~m}$ from the soil surface. Roots were also taken from a soil volume collected in two pits of $0.20 \mathrm{~m}$ width $\times 0.20 \mathrm{~m}$ length $\times 0.20 \mathrm{~m}$ depth. Pits were opened beside the grapevine row, corresponding to the area beneath the plant canopy, where ${ }^{15} \mathrm{~N}$ fertilizer has been applied. Soil was removed from the roots by washing the roots with distilled water and roots were reserved for analysis. Leaves, shoots, 1-year-old shoots, stems, and root samples were oven-dried with air circulation at $65^{\circ} \mathrm{C}$ until constant weight, and were sieved $(0.05 \mathrm{~mm}$ sieve $)$ and kept for analysis.

In the same pits where roots were taken, soil samples were collected in February 2011 at $0-0.05,0.05-0.10$ and $0.10-0.20 \mathrm{~m}$ depth. Soil samples were air dried, sieved and analyzed.

\subsection{Plant and soil analysis}

Total $\mathrm{N}$ and atom $\%{ }^{15} \mathrm{~N}$ enrichment in the plant organs and soil samples were analyzed by dry combustition and mass spectrophotometer (Hydra 20/20 model, PDZ Europa, Crewe, UK), respectively. The ${ }^{15} \mathrm{~N}$ dilution technique was used to estimate the atom $\%{ }^{15} \mathrm{~N}$ excess in the plant organs and soil, and the $\%{ }^{15} \mathrm{~N}$ recovery in each organ and soil layer, as follows (Brunetto et al., 2014):

The atom $\%{ }^{15} \mathrm{~N}$ excess was calculated according to Eq. (1):

Atom $^{15} \mathrm{~N}$ excess in sample $(\%)=\%$ atom $^{15} \mathrm{~N}$ in sample $-0.3663 \%$

where ${ }^{15} \mathrm{~N}$ from natural abundance in the atmosphere is $0.3663 \%$ enrichment and is assumed as reference.

The nitrogen derived from fertilizer (\%Ndff) was calculated using Eq. (2):

Nitrogen derived from fertilizer $(\%)=\frac{\% a t o m^{15} \mathrm{~N} \text { excess in sample }}{\% \text { atom }{ }^{15} \mathrm{~N} \text { excess in fertilizer }} \times 100$

The nitrogen derived from other sources, especially from the soil (\%Ndfs) was calculated using Eq. (3):

$$
\begin{aligned}
& \text { Nitrogen derived from othersources }(\%)=100-\text { nitrogen derived } \\
& \text { from fertilizer }
\end{aligned}
$$

\subsection{Statistical analysis}

Data were subjected to Analysis of Variance and when this analysis indicated statistically significant differences, data were subjected to the Scott-Knott mean comparison test for $\mathrm{p}<0.05$. 
Table 4

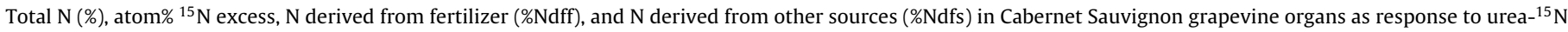
applied in the previous season.

\begin{tabular}{|c|c|c|c|c|c|c|c|}
\hline Treatment & Leaves & Berries + Rachis & Shoots & 1-year-old shoots & Stem & Roots & $\mathrm{CV}(\%)$ \\
\hline & Total N (\%) & & & & & & \\
\hline $10 \mathrm{~B}+10 \mathrm{~F}$ & $1.41 \mathrm{aA}^{\mathrm{a}}$ & $0.47 \mathrm{aD}$ & $0.70 \mathrm{aC}$ & $0.67 \mathrm{aC}$ & $0.41 \mathrm{aD}$ & $1.17 \mathrm{bB}$ & 8.10 \\
\hline $20 B+20 F$ & $1.41 \mathrm{aA}$ & $0.44 \mathrm{aC}$ & $0.69 \mathrm{aB}$ & $0.60 \mathrm{aB}$ & $0.38 \mathrm{aC}$ & $1.44 \mathrm{aA}$ & 10.35 \\
\hline $20 \mathrm{~B}$ & $1.25 \mathrm{bA}$ & $0.59 \mathrm{aB}$ & $0.64 \mathrm{aB}$ & $0.62 \mathrm{aB}$ & $0.39 \mathrm{aC}$ & $1.17 \mathrm{bA}$ & 14.23 \\
\hline $40 \mathrm{~F}$ & $1.21 \mathrm{bA}$ & $0.50 \mathrm{aC}$ & $0.68 \mathrm{aB}$ & $0.59 \mathrm{aB}$ & $0.36 \mathrm{aC}$ & $1.32 \mathrm{aA}$ & 14.39 \\
\hline \multirow[t]{2}{*}{ CV (\%) } & 13.10 & 17.89 & 5.22 & 11.52 & 4.94 & 4.00 & \\
\hline & \multicolumn{7}{|c|}{ Atom $\%{ }^{15} \mathrm{~N}$ excess } \\
\hline $10 \mathrm{~B}+10 \mathrm{~F}$ & $0.033 \mathrm{aC}$ & $0.030 \mathrm{aB}$ & $0.072 \mathrm{cA}$ & $0.045 \mathrm{aB}$ & $0.057 \mathrm{aA}$ & $0.060 \mathrm{bA}$ & 9.40 \\
\hline $20 \mathrm{~B}+20 \mathrm{~F}$ & $0.038 \mathrm{aC}$ & $0.034 \mathrm{aC}$ & $0.096 \mathrm{bA}$ & $0.070 \mathrm{aB}$ & $0.066 \mathrm{aB}$ & $0.080 \mathrm{aB}$ & 15.11 \\
\hline $20 \mathrm{~B}$ & $0.020 \mathrm{bD}$ & $0.016 \mathrm{bD}$ & $0.121 \mathrm{aA}$ & $0.059 \mathrm{aC}$ & $0.072 \mathrm{aC}$ & $0.086 \mathrm{aB}$ & 19.40 \\
\hline $40 \mathrm{~F}$ & $0.042 \mathrm{aC}$ & $0.041 \mathrm{aC}$ & $0.094 \mathrm{bA}$ & $0.055 \mathrm{aC}$ & $0.068 \mathrm{aB}$ & $0.053 \mathrm{bc}$ & 19.95 \\
\hline \multirow[t]{2}{*}{ CV (\%) } & 14.15 & 22.15 & 16.31 & 15.51 & 13.82 & 13.90 & \\
\hline & \multicolumn{7}{|l|}{$\%$ Ndff } \\
\hline $10 \mathrm{~B}+10 \mathrm{~F}$ & $1.10 \mathrm{aC}$ & $1.00 \mathrm{aB}$ & $2.40 \mathrm{cA}$ & $1.50 \mathrm{aB}$ & $1.91 \mathrm{aA}$ & $2.01 \mathrm{bA}$ & 9.33 \\
\hline $20 B+20 F$ & $1.27 \mathrm{aC}$ & $1.13 \mathrm{aC}$ & $3.19 \mathrm{bA}$ & $2.33 \mathrm{aB}$ & $2.19 \mathrm{aB}$ & $2.68 \mathrm{aB}$ & 15.19 \\
\hline $20 \mathrm{~B}$ & $0.68 \mathrm{bD}$ & $0.54 \mathrm{bD}$ & $4.04 \mathrm{aA}$ & $1.96 \mathrm{aC}$ & $2.39 \mathrm{aC}$ & $2.88 \mathrm{aB}$ & 19.31 \\
\hline $40 \mathrm{~F}$ & $1.40 \mathrm{aC}$ & $1.37 \mathrm{aC}$ & $3.12 \mathrm{bA}$ & $1.83 \mathrm{aC}$ & $2.27 \mathrm{aB}$ & $1.75 \mathrm{bC}$ & 19.65 \\
\hline \multirow[t]{2}{*}{ CV (\%) } & 13.74 & 21.81 & 16.20 & 15.32 & 13.68 & 13.84 & \\
\hline & \multicolumn{7}{|l|}{$\%$ Ndfs } \\
\hline $10 \mathrm{~B}+10 \mathrm{~F}$ & $98.90 \mathrm{bA}$ & $99.00 \mathrm{bA}$ & $97.60 \mathrm{aB}$ & $98.50 \mathrm{aA}$ & $98.09 \mathrm{aB}$ & $97.99 \mathrm{aB}$ & 0.16 \\
\hline $20 B+20 F$ & $98.73 \mathrm{bA}$ & $98.87 \mathrm{bA}$ & $96.81 \mathrm{bC}$ & $97.67 \mathrm{aB}$ & $97.81 \mathrm{aB}$ & $97.32 \mathrm{bB}$ & 0.33 \\
\hline $20 B$ & $99.32 \mathrm{aA}$ & $99.46 \mathrm{aA}$ & $95.96 \mathrm{cC}$ & $98.04 \mathrm{aB}$ & $97.61 \mathrm{aB}$ & 97.12 bD & 0.41 \\
\hline $40 \mathrm{~F}$ & $98.60 \mathrm{bA}$ & $98.63 \mathrm{bA}$ & $96.88 \mathrm{bC}$ & $98.17 \mathrm{aA}$ & $97.73 \mathrm{aB}$ & $98.25 \mathrm{aA}$ & 0.39 \\
\hline CV (\%) & 0.15 & 0.22 & 0.53 & 0.30 & 0.31 & 0.33 & \\
\hline
\end{tabular}

a Mean values followed by the same lowercase in the column and uppercase in the line do not differ among them by according to the Scott-Knott test at $5 \%$ prob-

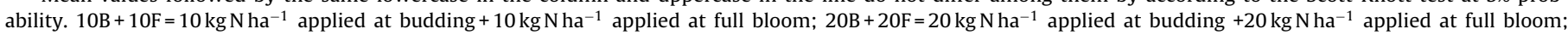
$20 \mathrm{~B}=20 \mathrm{~kg} \mathrm{~N} \mathrm{ha}^{-1}$ applied at budding; $40 \mathrm{~F}=20 \mathrm{~kg} \mathrm{~N}^{-1}$ applied at budding; $\mathrm{CV}=$ coefficient of variation.

\section{Results and discussion}

\section{1. $N$ distribution in the grapevine}

In the 2009/2010 crop season, the greatest concentration of total $\mathrm{N}$ was observed in the leaves of grapevines that received $20 \mathrm{~kg} \mathrm{Nha}^{-1}$ at budding $+20 \mathrm{~kg} \mathrm{Nha}^{-1}$ at full bloom $(20 \mathrm{~B}+20 \mathrm{~F})$ in comparison with other treatments (Table 3). Yet, the total $\mathrm{N}$ concentration in berries and rachis was not statistically different among treatments. By the addition of $10 \mathrm{~B}+10 \mathrm{~F}$ and $20 \mathrm{~B}+20 \mathrm{~F}$ at full bloom, a higher $(p<0.05)$ concentration of total $N$ was observed in leaves as compared with berries and rachis (Table 3 ). Similarly, in grapevines with application of $20 \mathrm{~kg} \mathrm{~N} \mathrm{ha}^{-1}$ at budding (20B) and $40 \mathrm{~kg} \mathrm{Nha}^{-1}$ at full bloom (40F), a higher concentration of total $\mathrm{N}$ was observed in leaves and rachis as compared with berries (Table 3, Fig. 1).

Among grapevine organs, the highest atom $\%{ }^{15} \mathrm{~N}$ excess and $\% \mathrm{Ndff}$ applied in the year was measured in the leaves and rachis with the addition of $20 \mathrm{~B}$, and no statistical difference was observed for other treatments (Table 3, Fig. 1). As expected, the lowest concentration of $\mathrm{N}$ derived from other sources (\%Ndfs) was observed in the leaves and rachis of grapevines fertilized with 20B (Table 3). Thus, leaves and rachis represent a physiological N sink during the vegetative and productive growth of grapevines (Glad et al., 1994; Schreiner and Scagel, 2006; Brunetto et al., 2014). However, the \%Ndff in leaves, rachis and berries was low, smaller than $7.3 \%$ for all treatments indicating that more than $92.7 \%$ of $\mathrm{N}$ in these organs was derived from other sources than the urea- ${ }^{15} \mathrm{~N}$, including internal $\mathrm{N}$, the soil $\mathrm{N}$, plant $\mathrm{N}$ reserves, irrigation water, etc. The low \%Ndff recovered in grapevine organs in the year of urea- ${ }^{15} \mathrm{~N}$ application is attributed to the dilution effect of fertilizer $\mathrm{N}$ in the plant which is mobilized to these new organs (Nikolaidou et al., 2010; Agnelli et al., 2014), assuming that roots are active at these growth phases. In previous studies, Conradie (1990, 1991), Löhnertz (1991), Glad et al. (1994), Araujo et al. (1995) and Eissenstat (2007) observed a large number of young roots which were a little active but were responsible for the crop water and fertilizer $\mathrm{N}$ uptake.

In the following season (2010/2011), the highest total $\mathrm{N}$ concentration was observed, especially in leaves of grapevines with the addition of $10 \mathrm{~B}+10 \mathrm{~F}$ and $20 \mathrm{~B}+20 \mathrm{~F}$ (Table 4, Fig. 2), confirming the results observed in the previous season. Unlike, roots presented the highest total $\mathrm{N}$ concentration by the addition of $20 \mathrm{~B}+20 \mathrm{~F}$ and $40 \mathrm{~F}$. The total $\mathrm{N}$ concentration in berries + rachis, 1 -year-old shoots, shoots and stem was not affected by treatments. For most treatments in this season, total $\mathrm{N}$ concentration followed the sequence: leaves $>$ roots $>1$-year-old shoots $=$ shoots $>$ berries + rachis $=$ stem .

The highest atom\% ${ }^{15} \mathrm{~N}$ excess and \%Ndff applied in the previous season was observed in the leaves and berries + rachis of grapevines by the addition of $10 \mathrm{~B}+10 \mathrm{~F}, 20 \mathrm{~B}+20 \mathrm{~F}$ and $40 \mathrm{~F}$ (Table 4, Fig. 2). In the shoots, the highest atom $\%{ }^{15} \mathrm{~N}$ excess and $\%$ Ndff was measured in grapevines under the $20 \mathrm{~B}$ treatment and in $20 \mathrm{~B}+20 \mathrm{~F}$, and in roots for $20 \mathrm{~B}$ treatment. In the 1 -year-old shoots, shoots and stem no significant response to treatments was observed. As to treatment $10 \mathrm{~B}+10 \mathrm{~F}$, the atom $\%{ }^{15} \mathrm{~N}$ excess and \%Ndff varied in the plant organs according to the sequence: shoots $=$ stem $=$ roots $>1$-year-old shoots $=$ berries + rachis $>$ leaves, similar to the application of double amount of $\mathrm{N}(20 \mathrm{~B}+20 \mathrm{~F})$ : shoots $>1$-year-old shoots $=$ stem $=$ roots $>$ leaves $=$ berries + rachis . With the addition of 20B, the order was similar: shoots $>$ roots $>1$ year-old shoots $=$ stem $>$ leaves $=$ berries + rachis. Finally, by the addition of $40 \mathrm{~F}$ in the previous year, the atom\% ${ }^{15} \mathrm{~N}$ excess and \%Ndff in plant organs again followed a similar sequence: shoots $>$ stem $>$ roots $=1$-year-old shoot $=$ leaves $=$ berries + rachis .

The greatest \%Ndfs was observed in leaves and berries + rachis in the grapevines provided with $20 \mathrm{~B}$ in the previous year (Table 4 ), in the shoots by the addition of $10 \mathrm{~B}+10 \mathrm{~F}$, and in the roots by addition of $10 \mathrm{~B}+10 \mathrm{~F}$ and $40 \mathrm{~F}$. Treatments did not affect the $\%$ Ndfs in 1 -yearold shoots and stems. The treatment $10 \mathrm{~B}+10 \mathrm{~F}$ affected significantly $\% \mathrm{Ndfs}$ in the following order: leaves = berries + rachis $=1$ year-old shoots $=$ shoots $=$ stem $=$ roots. The $\%$ Ndfs in plant organs followed the order: leaves = berries + rachis $>1$-year- 


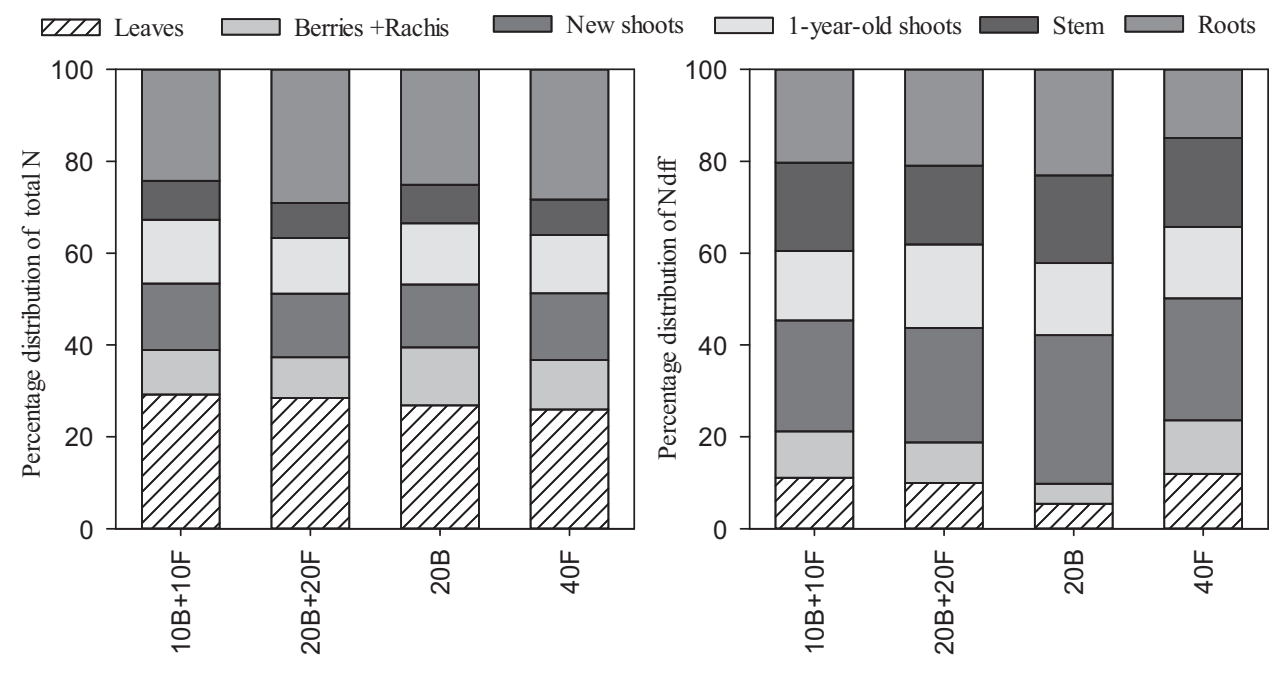

Treatment

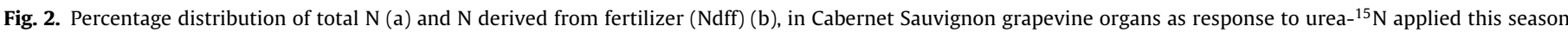

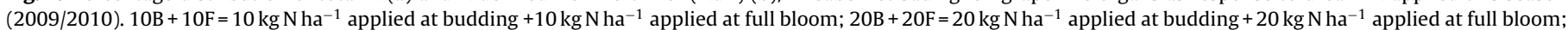
$20 \mathrm{~B}=20 \mathrm{~kg} \mathrm{~N} \mathrm{ha}^{-1}$ applied at budding; $40 \mathrm{~F}=20 \mathrm{~kg} \mathrm{~N} \mathrm{ha}^{-1}$ applied at budding.

old shoots $=$ stem $=$ roots, and was the opposite of \%Ndff in plant organs by double $\mathrm{N}$ fertilizer $(20 \mathrm{~B}+20 \mathrm{~F})$ and the $20 \mathrm{~B}$. This shows that most $\mathrm{N}$ in these plant organs came from other sources, as the internal $\mathrm{N}$ reserves and soil $\mathrm{N}$ (Brunetto et al., 2006b; Menino et al., 2007; Neto et al., 2008; Nikolaidou et al., 2010; Agnelli et al., 2014). Fertilizer $\mathrm{N}$ applied in the previous season was accumulated mostly in the reserve organs: stem, roots and shoots. This ${ }^{15} \mathrm{~N}$ accumulated in the reserve organs was remobilized for the new organs in the following season. As demonstrated by Menino et al. (2007) for perennial orange trees and Neto et al. (2008) for pear trees, fertilizer $\mathrm{N}$ applied in the year is mobilized to the young organs during the vegetative and flowering phases, and when is applied at harvest, $\mathrm{N}$ is accumulated in the reserve organs (stem, roots, shoots) to be translocated for the new flush in the following year. Leaves are the most enriched plant $\mathrm{N}$ organ from fertilizer $\mathrm{N}$ applied in the year, especially at bloom.

\section{2. $N$ distribution in the soil}

In the soil, the highest $(\mathrm{p}<0.05)$ concentration of total $\mathrm{N}$ for all treatments was observed in the surface layer $(0.0-0.05 \mathrm{~m})$ and the lowest level was measured for the $40 \mathrm{~B}$ treatment added in the previous season (Table 1 ). In the $0.05-0.10$ and $0.10-0.20 \mathrm{~m}$ soil layers, the total $\mathrm{N}$ concentration did not vary $(\mathrm{p} \geq 0.05)$ among treatments (Table 5).

The higher \%Ndff was observed in the surface layer regardless of treatment. In the surface layer $(0-0.05)$, the highest atom $\%{ }^{15} \mathrm{~N}$ excess and \%Ndff was measured under the highest $\mathrm{N}$ rates applied in the previous season $(20 \mathrm{~B}+20 \mathrm{~F}$ and $40 \mathrm{~F})$ (Table 5). In contrast, the lowest atom $\%{ }^{15} \mathrm{~N}$ excess and \%Ndff was observed under the 20B treatment applied in the previous year. In the $0.05-0.10 \mathrm{~m}$ soil layer, atom\% ${ }^{15} \mathrm{~N}$ excess and \%Ndff were higher $(\mathrm{p}<0.05)$ under the $20 \mathrm{~B}$ and $40 \mathrm{~F}$ treatment. In the $0.10-0.20 \mathrm{~m}$ soil layer, no significant differences of atom $\%{ }^{15} \mathrm{~N}$ excess and \%Ndff were found for all treatments applied.

The lowest atom $\%{ }^{15} \mathrm{~N}$ excess and \%Ndff in the surface layer with $20 \mathrm{~B}$ may be attributed to the greater fertilizer $\mathrm{N}$ uptake by grapevines in the first crop season (2009/2010), diagnosed by the increase in the concentration of atom $\%{ }^{15} \mathrm{~N}$ excess and \%Ndff in the leaves and berries + rachis (Table 3), but also to some movement of ${ }^{15} \mathrm{~N}$ in the soil profile to the 2 nd layer.
Table 5

Residual total $\mathrm{N}(\%)$, atom\% ${ }^{15} \mathrm{~N}$ excess, and $\mathrm{N}$ derived from fertilizer (\%Ndff) measured on February 2011 in soil planted with Cabernet Sauvignon grapevine after application of urea- ${ }^{15} \mathrm{~N}$ in 2009.

\begin{tabular}{|c|c|c|c|c|}
\hline \multirow[t]{2}{*}{ Treatment } & \multicolumn{3}{|l|}{ Layer (m) } & \multirow[t]{2}{*}{$\mathrm{CV}(\%)$} \\
\hline & $0-0.05$ & $0.05-0.10$ & $0.10-0.20$ & \\
\hline & Total N (\%) & & & \\
\hline $10 \mathrm{~B}+10 \mathrm{~F}$ & $0.07 \mathrm{aA}^{\mathrm{a}}$ & $0.04 \mathrm{aB}$ & $0.03 \mathrm{aB}$ & 20.68 \\
\hline $20 \mathrm{~B}+20 \mathrm{~F}$ & $0.07 \mathrm{aA}$ & $0.03 \mathrm{aB}$ & $0.04 \mathrm{aB}$ & 9.33 \\
\hline $20 \mathrm{~B}$ & $0.06 \mathrm{aA}$ & $0.04 \mathrm{aB}$ & $0.03 \mathrm{aC}$ & 6.88 \\
\hline $40 \mathrm{~F}$ & $0.04 \mathrm{bA}$ & $0.03 \mathrm{aB}$ & $0.03 a \mathrm{~B}$ & 8.69 \\
\hline \multirow[t]{2}{*}{ CV (\%) } & 14.08 & 10.19 & 11,56 & \\
\hline & \multicolumn{3}{|c|}{ Atom $\%{ }^{15} \mathrm{~N}$ excess } & \\
\hline $10 \mathrm{~B}+10 \mathrm{~F}$ & $0.129 \mathrm{bA}$ & $0.038 \mathrm{bB}$ & $0.026 \mathrm{aB}$ & 22.79 \\
\hline $20 \mathrm{~B}+20 \mathrm{~F}$ & $0.177 \mathrm{aA}$ & $0.068 \mathrm{bB}$ & $0.050 \mathrm{aB}$ & 15.76 \\
\hline $20 \mathrm{~B}$ & $0.085 \mathrm{cA}$ & $0.112 \mathrm{aA}$ & $0.024 \mathrm{aB}$ & 14.46 \\
\hline $40 \mathrm{~F}$ & $0.194 \mathrm{aA}$ & $0.137 \mathrm{aB}$ & $0.055 \mathrm{aC}$ & 14.47 \\
\hline \multirow[t]{2}{*}{ CV (\%) } & 23.15 & 7.81 & 16.04 & \\
\hline & $\%$ Ndff & & & \\
\hline $10 \mathrm{~B}+10 \mathrm{~F}$ & $4.29 \mathrm{bA}$ & $1.26 \mathrm{bB}$ & $0.87 \mathrm{aB}$ & 22.38 \\
\hline $20 \mathrm{~B}+20 \mathrm{~F}$ & $5.91 \mathrm{aA}$ & $2.27 \mathrm{bB}$ & $1.66 \mathrm{aB}$ & 15.86 \\
\hline $20 \mathrm{~B}$ & $2.83 \mathrm{cA}$ & $3.72 \mathrm{aA}$ & $0.78 \mathrm{aB}$ & 14.14 \\
\hline $40 \mathrm{~F}$ & $6.47 \mathrm{aA}$ & $4.56 \mathrm{aB}$ & $1.84 \mathrm{aC}$ & 18.60 \\
\hline CV (\%) & 23.11 & 7.74 & 16.59 & \\
\hline
\end{tabular}

a Mean values followed by the same lowercase in the column and uppercase in the line do not differ among them according to the Scott-Knott test at 5\% probability. $10 \mathrm{~B}+10 \mathrm{~F}=10 \mathrm{~kg} \mathrm{Nha}^{-1}$ applied at budding $+10 \mathrm{~kg} \mathrm{Nha}^{-1}$ applied at full bloom; $20 \mathrm{~B}+20 \mathrm{~F}=20 \mathrm{~kg} \mathrm{Nha}^{-1}$ applied at budding $+20 \mathrm{~kg} \mathrm{Nha}^{-1}$ applied at full bloom; $20 \mathrm{~B}=20 \mathrm{~kg} \mathrm{Nha}^{-1}$ applied at budding; $40 \mathrm{~F}=20 \mathrm{~kg} \mathrm{~N} \mathrm{ha}^{-1}$ applied at budding; $\mathrm{CV}=$ coefficient of variation.

\section{Conclusions}

Grapevines for wine production grown in a sandy soil took up more $\mathrm{N}$ derived from fertilizer applied at a rate of $40 \mathrm{~kg} \mathrm{~N} \mathrm{ha}^{-1}$ split at budding and full bloom in the first season. This fertilizer $\mathrm{N}$ was preferentially recovered in annual plant organs (leaves and berries + rachis). Unlike, in the following season (2010/2011), fertilizer $\mathrm{N}$ applied in the previous year was recovered especially in reserve organs, such as the stem, roots and shoots, whereas leaves and berries + rachis showed the lowest ${ }^{15} \mathrm{~N}$ recovery. Nitrogen in both seasons was mainly derived from other sources than the fertilizer $\mathrm{N}$. 


\section{Conflicts of interest}

The authors declare no financial or other competing conflicts of interest.

\section{Acknowledgements}

We are grateful to the CAPES (Edital 034/2007) for scholarships and other financial support. Our thanks are also due to the CNPq for the research productivity grant offered to the first author.

\section{References}

Agnelli, A., Bol, R., Trumborec, S.E., Dixond, L., Coccoe, S., Corti, G., 2014. Carbon and nitrogen in soil and vine roots in harrowed and grass-covered vineyards. Agric. Ecosyst. Environ. 193, 70-82.

Araujo, F., Williams, L.E., Matthews, M.A.A., 1995. Comparative study of young Thompson Seedless grapevines (Vitis vinifera L.) under drip and furrow irrigation. II. Growth, water use efficiency and nitrogen partitioning. Sci. Hortic. 60, 251-265.

Barlow, K., Bond, W., Holzapfel, B., Smith, J., Hutton, R., 2009. Nitrogen concentrations in soil solutionand surface run-off on irrigated vineyards in Austrália. Aust. J. Grape Wine Res. 15, 31-143.

Bates, T.R., Dunst, R.M., Joy, P., 2002. Seasonal dry matter starch, and nutrient distribution in Concord grapevine roots. HortScience 37, 313-316.

Brunetto, G., Kaminski, J., Melo, G.W.B., Gatiboni, L.C., Urquiaga, S., 2005. Absorção e redistribuição do nitrogênio aplicado via foliar em videiras jovens. Rev. Bras. Frutic. 27, 110-114.

Brunetto, G., Kaminski, J., Melo, G.W.B., Rheinheimer, D.S., 2006a. Recuperação e distribuição do nitrogênio fornecido a videiras jovens. Pesq. Agropec. Bras. 41, 1299-1304.

Brunetto, G., Kaminski, J., Melo, G.W.B., Bruning, F.S., Mallmann, F.J.K., 2006b. Destino do nitrogênio em videiras Chardonnay e Riesling Renano quando aplicado no inchamento das gemas. Rev. Bras. Frutic. 28, 497-500.

Brunetto, G., Ceretta, C.A., Kaminski, J., Melo, G.W.B., Lourenzi, C.R., Furlanetto, V., Moraes, A., 2007. Aplicação de nitrogênio em videiras na Campanha Gaúcha: Produtividade e características químicas do mosto da uva. Ciência Rural 37, 389-393.

Brunetto, G., Ventura, M., Scandellari, F., Ceretta, C.A., Kaminski, J., Melo, G.W.B. Tagliavini, M., 2011. Nutrients release during the decomposition of mowed perennial ryegrass and white clover and its contribution to nitrogen nutrition of grapevine. Nutr. Cycl. Agroecosyst. 90, 299-308.

Brunetto, G., Ceretta, C.A., Melo, G.W.B., Kaminski, J., Trentin, G., Girotto, E., Ferreira, P.A.A., Miotto, E., Trivelin, P.C.O., 2014. Contribution of nitrogen from agricultural residues of rye to 'Niagara Rosada' grape nutrition. Sci. Hortic. 169, 66-70.
COFS-RS/SC (Comissão de Química e Fertilidade do Solo-RS/SC), 2004. Manual de adubação e calagem para os Estados do Rio Grande do Sul e de Santa Catarina. SBCS-Núcleo Regional Sul/UFRGS, Porto Alegre.

Conradie, W.J., 1990. Distribution and translocation of nitrogen absorbed during late spring by two-year-old grapevines grown in sand culture. Am. J. Enol. Vitic. 41, 241-250.

Conradie, W.J., 1991. Distribution and translocation of nitrogen absorbed during early summer by two-year-old grapevines grown in sand culture. Am. J. Enol. Vitic. 42, 180-190.

Eissenstat, D.M., 2007. Dinamica di crescita delle radici nelle colture da frutto. Italus Hortus 14, 1-8.

Glad, C., Farineau, J., Regnard, J.L., Morot-Gaudry, J.L., 1994. The relative contribution of nitrogen originating from two seasonal ${ }^{15} \mathrm{~N}$ supplies to the total nitrogen pool present in the bleeding sap and in whole Vitis vinifera $\mathrm{cv}$. Pinot noir grapevines at bloom time. Am. J. Enol. Vitic. 45, 327-332.

Hajrasuliha, S., Rolston, D.E., Louie, D.T., 1998. Fate of $15 \mathrm{~N}$ fertilizer applied to trickle-irrigated grapevines. Am. J. Enol. Vitic. 49, 191-198.

Löhnertz, O., 1991. Soil nitrogen and the uptake of nitrogen in grapevines. In: International Symposium on Nitrogen in Grapes and Wine, 1991, Washington. The American Society for Enology and Viticulture, Washington, pp. 1-11.

Lorensini, F., Ceretta, C.A., Girotto, E., Cerini, J.B., Lourenzi, C.R., De Conti, L. Trindade, M.M., Melo, G.W.B., Brunetto, G., 2012. Lixiviação e volatilização de nitrogênio em um Argissolo cultivado com videira submetida à adubação nitrogenada. Ciência Rural 42, 1173-1179.

Menino, M.R., Carranca, C., Varennes, A., 2007. Distribution and remobilization of nitrogen in young non-bearing orange trees grown under mediterranean conditions. J. Plant Nutr. 30, 1083-1096.

Neto, C., Carranca, C., Clemente, J., de Varennes, A., 2008. Nitrogen distribution, remobilization and re-cycling in young orchard of non-bearing 'Rocha' pear trees. Sci. Hortic. 118, 299-307.

Nielsen, D.R., Biggar, J.W., Wierenga, P.J., 1982. Nitrogen transport process in soil In: Stevenson, P.J. (Ed.), Nitrogen in Agriculture Soils. American Society of Agronomy, Madison, pp. 423-448.

Nikolaidou, A.E., Pavlatou-Ve, A.K., Kostopoulou, S.K., Mamolos, A., Kalburtji, K.L., 2010. Litter quality and decomposition of Vitis vinifera L. residues under organic and conventional farming systems. Eur. J. Soil Biol. 46, 208-217.

Schreiner, R.P., Scagel, C.F., 2006. Nutrient uptake and distribution in a mature 'Pinot Noir' vineyard. HortScience 41, 336-345.

Spayd, S.E., Wample, R.L., Nagel, C.W., Stevens, R.G., Evans, R.G., 1991. Vineyard nitrogen fertilization effects on must and wine composition and quality. In: International Symposium on Nitrogen in Grapes and Wine. The American Society for Enology and Viticulture, pp. 196-199.

Vos, R.J., Zabadal, T.J., Hanson, E.J., 2004. Effect of nitrogen application timing on N uptake by Vitis labrusca in a short-season region. Am. J. Enol. Vitic. (Davis) 55, 246-252.

Zapata, C., Deléens, E., Chaillou, S., Magné, C., 2004. Partitioning and mobilization of starch and $\mathrm{N}$ reserves in grapevine (Vitis vinifera L.). J. Plant Physiol. 161 1031-1040 